Acta Protozool. (2017) 56: 303-315

www.ejournals.eu/Acta-Protozoologica

doi:10.4467/16890027AP.17.026.7828

PROTOZOOLOGICA

\title{
Description of a New Brackish Water Ciliate, Uronychia xinjiangensis n. sp. (Ciliophora, Euplotida) Based on Morphology, Morphogenesis and Molecular Phylogeny
}

\author{
Xinlu SHI ${ }^{1}$, Guijie LIU ${ }^{1}$, Chundi WANG ${ }^{2}$, Xiaozhong HU $^{2}$ \\ ${ }^{1}$ Hangzhou Key Laboratory of Animal Adaptation and Evolution, Hangzhou Normal University, Hangzhou, China; ${ }^{2}$ Institute of \\ Evolution and Marine Biodiversity \& College of Fisheries, Ocean University of China, Qingdao, China
}

\begin{abstract}
A brackish water euplotid ciliate, Uronychia xinjiangensis n. sp., was discovered in a ditch in Yuli County, Xinjiang, China. Its morphology, ciliature and morphogenesis were investigated based on specimens examined in vivo and following protargol staining. The new species is characterized by the posterior part of the adoral zone composed of three membranelles, which has never been seen in all other known congeners. Other morphologic features include: (i) body oval-shaped, with conspicuous right anterior spur-like protrusion; (ii)size in vivo 60-90 × 40-68 $\mu \mathrm{m}$; (iii) two macronuclear nodules; (iv) four frontal, two ventral, five transverse, three left marginal and three caudal cirri. Its morphogenesis proceeds in a usual way, except that the oral primordium forms only three proximal membranelles rather than four proximal membranelles within congeners. The small subunit rRNA gene of the new species (GenBank accession number: KX147287) comprises $1723 \mathrm{bp}$ and $44.63 \%$ GC content, and differs by $0.12-1.81 \%$ from those of congeners. Phylogenetic analyses based on SSU rRNA gene sequence data reveal that Uronychia xinjiangensis n. sp. clusters with other Uronychia species with full support, which supports the monophyly of the genus Uronychia Stein, 1859.
\end{abstract}

Key words: euplotids, Uronychia, ciliature, ontogeny, SSU rDNA

\section{INTRODUCTION}

The euplotid genus Uronychia Stein, 1859 is commonly found in marine and saltwater biotopes, thus has a very long research history (e.g. Müller 1786; Stein 1859; Wallengren 1900; Young 1922; Mansfeld 1923;

Address for correspondence: Xinlu Shi, Hangzhou Normal University, Hangzhou 310036, China; E-mail: shix156@163.com; Tel.: +86 158 68472538; Xiaozhong Hu, Institute of Evolution and Marine Biodiversity \& College of Fisheries, Ocean University of China, Qingdao 266003, China; E-mail: xiaozhonghu@ouc.edu.cn; Tel.: +86 53282031610
Kahl 1932; Wang and Nie 1932; Kirby 1934; Bullington 1940; Kattar 1970; Agamaliev 1971; Borror 1972; Wilbert and Kahan 1981; Valbonesi and Luporini 1990; Carey 1992; Song 1997; Kim and Min 2011). Based on the revision by Curds and $\mathrm{Wu}(1983)$ and the redefinition by Song (1999), four morphospecies were considered as valid species in the genus, i.e. U. transfuga (Müller 1786) Stein, 1859 (type species), U. setigera Calkins, 1902, U. binucleata Young, 1922, and U. multicirrus Song, 1997.

Although Song and Wilbert (1997) significantly enhanced our knowledge about Uronychia populations based on morphometric analyses, some morphological 
features at the species level are weak and easily overlooked. For example, the separation of $U$. setigera and $U$. binucleata is based almost exclusively on cell size and on the difference in the number of basal body pairs in the leftmost dorsal kinety, the latter character only being discernible in high quality protargol preparations.

Morphogenetic studies revealed that Uronychia species have an extremely similar developmental pattern of cortical structures and nuclear apparatus (Calkins 1911; Taylor 1928; Wilbert and Kahan 1981; Hill 1990; Wilbert 1995; Song 1996; Shi and Song 1999; Song et al. 2004), which do not contribute too much to species separation within the genus.

Recently, molecular biology techniques improve our understanding of high genetic diversity among ciliates (Chen and Song 2001; Chen et al. 2003; Shen et al. 2009; Yi et al. 2009; Huang et al. 2012, 2014; Gao et al. 2017).

During a survey on fauna in Xinjiang, western China, a species of Uronychia was isolated and investigated. Based on morphological and SSU rDNA sequence comparison, we believe it represents a new one, Uronychia xinjiangensis $\mathrm{n}$. $\mathrm{sp}$.

\section{MATERIALS AND METHODS}

\section{Sampling and cultivation}

Water samples were collected from temporary ditches near the $891 \mathrm{~km}$ spot on the national road $218\left(40^{\circ} 25^{\prime} 47^{\prime \prime} \mathrm{N}, 88^{\circ} 1^{\prime} 27^{\prime \prime} \mathrm{E}\right)$, Yuli County, Xinjiang, China, where the altitude is $880 \mathrm{~m}$, on July 23 , 2007. The $\mathrm{pH}$ and salinity of water are 8.26 and $2-4 \%$, respectively. In the sample, only one kind of ciliate was found. After isolation, pure cultures were kept in the laboratory. For molecular work, clonal cultures were established and maintained in sterilized artificial brackish water at room temperature $\left(c a 20^{\circ} \mathrm{C}\right)$. Squeezed wheat grains were added to enrich bacterial food.

\section{Morphological and morphogenetic methods}

Specimens were examined in vivo using bright-field and differential interference contrast microscopy. The ciliature and nuclear apparatus of cells at non-dividing and dividing stages was revealed using an improved protargol impregnation method according to Shi (2006). The protargol product from Merck was used for staining. Photomicrographs were obtained using a Leica DM6000B Microsystems (Leica Microsystems GmbH, Wetzlar, Germany). Schematic drawings of specimens in vivo and of different stages of morphogenesis were hand-drawn on parchment paper, based on photomicrographs or using a camera lucida. To illustrate the changes occurring during morphogenetic stages, the parental cirri were drawn only by outline in diagrams, whereas the new ones are shaded black.

Terminology and systematics are according to Shen et al. (2009) and Lynn (2008), respectively.

\section{ZooBank registration}

ZooBank registration of present work (see Recommendation 8A of ICZN2012): urn:1sid:zoobank.org:pub:147B2320-4AD2-46CA-829E-D698F95E82BE

\section{DNA extraction, PCR amplification and sequencing}

DNA was extracted according to Chen and Song (2001). In brief, cells were starved in artificial, sterilized brackish water (salinity $4 \%$ ) at room temperature overnight to minimize the contaminants from food and other sources. They were harvested by centrifugation at $640 \mathrm{~g}$ for $3 \mathrm{~min}$ and treated with lysis buffer $(10 \mathrm{mM}$ Tris- $\mathrm{HCl}, \mathrm{pH} 8.3,50 \mathrm{mM} \mathrm{KCl}, 2.5 \mathrm{mM} \mathrm{MgCl}_{2}, 0.6 \%$ Tween 20 , $0.6 \%$ Nonidet P40, $60 \mathrm{mg} / \mathrm{ml}$ Proteinase $\mathrm{K}$ ) at $56^{\circ} \mathrm{C}$ for $2-3 \mathrm{~h}$, followed by phenol-chloroform purification. Universal primers $(18 \mathrm{sF}$ 5'-AACCTGGTTGATCCTGCCAGT-3'; 18sR 5'-TGATCCTTCTGCAGGTTCACCTAC-3') (Medlin et al. 1988) were used to amplify the SSU rRNA gene. The amplification profile consisted of 35 cycles of $30 \mathrm{~s}$ at $98^{\circ} \mathrm{C}, 30 \mathrm{~s}$ at $67^{\circ} \mathrm{C}$ and $1 \mathrm{~min}$ at $72^{\circ} \mathrm{C}$, followed by $5 \mathrm{~min}$ at $72^{\circ} \mathrm{C}$ for final extension. In order to minimize sequence errors, Q5 ${ }^{\circledR}$ Hot Start High-Fidelity DNA Polymerase (Cat. \#M0493L, New England Biolabs Inc. USA) was used for PCR amplification. PCR product was sequenced at the Tsingke biological technology Co., Ltd in Qingdao, China. The contig was assembled by SeqMan (DNASTAR).

\section{Phylogenetic analyses}

Phylogenetic analyses included the SSU rRNA gene sequence of Uronychia xinjiangensis $\mathrm{n}$. sp. and 44 other species, which were downloaded from NCBI GenBank database (accession numbers as shown in Fig. 7). Uronychia sinica (FJ876982) was an unpublished name (personal communication) and it is treated as Uronychia sp. in the present study. All sequences were aligned by a website of The GUIDANCE2 Server (Sela et al. 2015) with default settings and further manually modified using the program BioEdit 7.0.1 (Hall 1999), resulting in a matrix of 45 sequences and 1729 characters. Maximumlikelihood (ML) analysis was performed in CIPRES Science Gateway using RAxML-HPC2 on XSEDE 8.2.6 (Stamatakis et al. 2008) with the model GTR $+\mathrm{G}$. The reliability of internal branches was assessed using a nonparametric bootstrap method with 1000 replicates. Bayesian inference (BI) analysis was carried out using MrBayes on XSEDE 3.2.6 with the model GTR $+\mathrm{I}+\mathrm{G}$ (selected by MrModeltest v.2.0; Nylander, 2004) in CIPRES Science Gateway. Markov chain Monte Carlo simulations were run with two sets of four chains for $6,000,000$ generations with a frequency of 100 generations, and the first $25 \%$ of sampled trees were discarded as burn-in. MEGA 6.06 (Tamura et al. 2013) was used to visualize tree topologies.

\section{RESULTS}

\author{
Class Spiritrichea Bütschli, 1889 \\ Order Euplotida Small and Lynn, 1985 \\ Family Uronychiidae Jankowski, 1975 \\ Genus Uronychia Stein, 1859 \\ Uronychia xinjiangensis n. sp. (Figs 1-7, Tables 1 \\ and 2)
}




\section{Diagnosis}

Body oval-shaped, size about 60-90 × 40-68 $\mu \mathrm{m}$ in vivo. Two macronuclear nodules; the posterior part of adoral zone composted of three membranelles; always two fine ventral cirri and one small buccal cirrus; the dorsal kinety 1 consisting of about 36 basal body pairs. Brackish water habitat.

\section{Deposition of types}

The protargol slide with the holotype specimen (Fig. 1B, C) and paratypes was deposited in the Hangzhou Key Laboratory for Animal Adaptation and Evolution (registration number: 070723112), Hangzhou Normal University, Hangzhou, China.

\section{Type locality}

Brackish water ( $\mathrm{pH} 8.26$, salinity 2 4\%) from ditches in Yuli County $\left(40^{\circ} 25^{\prime} 47^{\prime \prime} \mathrm{N}, 88^{\circ} 1^{\prime} 27^{\prime \prime} \mathrm{E}\right)$, Xinjiang, China (for details, see Materials and Methods).

\section{Etymology}

The species-group name "xinjiangensis" refers to Xinjiang Province where the new species was discovered.

\section{Morphology}

Cell approximately oval-shaped, in vivo about 60 $90 \times 40-68 \mu \mathrm{m}(\mathrm{n}=13)$, mostly $80 \times 55 \mu \mathrm{m}$ (Figs 1 A, $4 \mathrm{~A}-\mathrm{D})$. When viewed ventrally, the right side is slightly even and the left side is arc-shaped (Figs 1A, 4A, B). Dorsoventrally ca. $1: 2$ flattened. A distinct spur-like protrusion on right anterior portion of body, while other protrusion inconspicuous (Figs 4B, F). Inconsistently two concaves present in posterior portion of cell on ventral side, which are the location of transverse and left marginal cirri, respectively. On dorsal side a large depression corresponding position of caudal cirri (CC) (Figs 1A, 4A-C, I).

Table 1. Morphometric characterization of Uronychia xinjiangenesis n. sp.

\begin{tabular}{|c|c|c|c|c|c|c|c|}
\hline Character & Min & Max & Mean & $\mathrm{M}$ & $\mathrm{SD}$ & $\mathrm{CV}$ & $\mathrm{n}$ \\
\hline Length of body $*(\mu \mathrm{m})$ & 60 & 90 & 77.1 & 76 & 3.64 & 4.7 & 13 \\
\hline Length of body $(\mu \mathrm{m})$ & 58 & 87 & 73.4 & 73 & 8.47 & 11.5 & 13 \\
\hline Width of body $*(\mu \mathrm{m})$ & 40 & 68 & 55.8 & 58 & 8.89 & 15.9 & 13 \\
\hline Width of body $(\mu \mathrm{m})$ & 39 & 66 & 53.8 & 56 & 8.47 & 15.7 & 13 \\
\hline Length of adoral zone $(\mu \mathrm{m})$ & 38 & 53 & 44.5 & 43 & 4.77 & 10.7 & 13 \\
\hline Number of membranelles in AZM1 & 11 & 11 & 11 & 11 & 0 & 0 & 15 \\
\hline Number of membranelles in AZM2 & 3 & 3 & 3 & 3 & 0 & 0 & 15 \\
\hline Number of buccal cirrus & 1 & 1 & 1 & 1 & 0 & 0 & 15 \\
\hline Number of frontal cirri & 4 & 4 & 4 & 4 & 0 & 0 & 15 \\
\hline Number of ventral cirri & 2 & 2 & 2 & 2 & 0 & 0 & 15 \\
\hline Number of left marginal cirri & 3 & 3 & 3 & 3 & 0 & 0 & 15 \\
\hline Number of caudal cirri & 3 & & 3 & 3 & 3 & 0 & 0 \\
\hline Number of transverse cirri & & 5 & 5 & 5 & 0 & 0 & 0 \\
\hline Number of dorsal kineties & 6 & 6 & 6 & 6 & 0 & 0 & 15 \\
\hline Number of macronuclear nodules & 2 & 2 & 2 & 2 & 0 & 0 & 15 \\
\hline Number of basal body pairs in DK1 & 34 & 38 & 36.3 & 34 & 1.41 & 3.9 & 9 \\
\hline Length of anterior $\mathrm{MN}(\mu \mathrm{m})$ & 45 & 48 & - & - & - & - & 4 \\
\hline Width of anterior MN $(\mu \mathrm{m})$ & 12 & 16 & - & - & - & - & 4 \\
\hline Length of posterior MN $(\mu \mathrm{m})$ & 24 & 28 & - & - & - & - & 4 \\
\hline Width of posterior $\mathrm{MN}(\mu \mathrm{m})$ & 17 & 19 & - & - & - & - & 4 \\
\hline
\end{tabular}

Data based on protargol-impregnated specimens. * from live cells. Abbreviations: AZM1, 2, the anterior and posterior part of adoral zone of membranelles; $\mathrm{CV}$, coefficient of variation in \%; DK 1, dorsal kinety 1; Max, maximum; Mean, arithmetic mean; M, median value; Min, minimum; MN, macronuclear nodule; $n$, number of specimens observed; SD, standard deviation. 
Table 2. Sequences divergence of SSU rRNA gene between Uronychia xinjiangensis $\mathrm{n}$. $\mathrm{sp}$. and congeners

\begin{tabular}{lcc}
\hline & $\begin{array}{c}\text { sequence } \\
\text { variation (bp) }\end{array}$ & $\begin{array}{c}\text { Sequence } \\
\text { similarity }\end{array}$ \\
\hline Uronychia transfuga AF260120 & 28 & $98.25 \%$ \\
Uronychia binucleata EF198667 & 26 & $98.38 \%$ \\
Uronychia binucleata $\mathrm{HQ380024}$ & 25 & $98.44 \%$ \\
Uronychia multicirrus EU267929 & 25 & $98.44 \%$ \\
Uronychia multicirrus $\mathrm{HQ380025}$ & 25 & $98.44 \%$ \\
Uronychia setigera EF198669 & 27 & $98.31 \%$ \\
Uronychia setigera $\mathrm{HQ380023}$ & 26 & $98.38 \%$ \\
Uronychia setigera $\mathrm{HQ380022}$ & 28 & $98.25 \%$ \\
Uronychia setigera $\mathrm{HQ380021}$ & 29 & $98.19 \%$ \\
Uronychia setigera $\mathrm{JF694042}$ & 21 & $98.69 \%$ \\
Uronychia sp. FJ876982 & 2 & $99.88 \%$ \\
\hline
\end{tabular}

Endoplasm colorless, comprising many to numerous granules ( $c a$. 1-5 $\mu \mathrm{m}$ in diameter), which renders cell grayish to dark gray at low magnification (Figs 1A, $4 \mathrm{~A}$ ). Food vacuoles (FV) recognizable, low in number, containing green algae and unidentified inclusions (Fig. 4B-D). Two macronuclear nodules connected by funiculus, left of cell midline; individual nodule oval to elongate ellipsoidal, up to $50 \mu \mathrm{m}$ long (Fig. 1C); micronuclei not observed in vivo or after protargol staining. Sometimes a small contractile vacuole located at the lower right-hand corner in buccal field (Fig. 4A, I).

The movement and behavior of the new species characteristic: they spend most of the time creeping and grazing on the substrate; they rapidly jump to elude backwards when stimulated, and swim very fast in the water, rotating around their longitudinal axes; the adoral membranelles and cirri stiffly spread during pauses.

Buccal field enormous, extending to $61 \%$ of body length on average in protargol preparations (Figs 1A, 4D, J). Constantly 11 adoral membranelles in anterior part (AZM1), mostly extending onto dorsal side (Fig. 5A, B, D); cilia of membranelles $15-25 \mu \mathrm{m}$ long. Posterior part of adoral zone (AZM2) composed of three membranelles (Table 1), in which basal bodies are arranged in four rows and cilia are 12-16 $\mu \mathrm{m}$ long (Figs $4 \mathrm{G}, 5 \mathrm{G})$. Single buccal cirrus (BC) $12-15 \mu \mathrm{m}$ long, apart from AZM2 (Fig. 4G). Paroral membrane (PM) genus-specific, that is, highly developed and forming almost a circle with $\mathrm{BC}$ and AZM2; cilia of PM about $30 \mu \mathrm{m}$ long (Figs 1A, B, 5A).
Somatic ciliature distributed on ventral and dorsal side: constantly four fine frontal cirri (FC; Table 1) resembling short membranelles in anterior right area of body (Figs 4H, 5E). Two fine ventral cirri (VC) near right posterior border of cell (Figs 4J, arrows; 5F, arrows). Cilia of both frontal and ventral cirri about $15 \mu \mathrm{m}$ long. Always five transverse cirri (TC), four left ones considerably enlarged and about $40-45 \mu \mathrm{m}$ long each and rightmost cirrus small and inconspicuous (Figs 1A, 4G, I). Three left marginal cirri (LMC; Table 1), curving to right at their distal ends, the uppermost one is extraordinary small while the middle one is considerably enlarged, and its cilia measures $45 \mu \mathrm{m}$ in length (Figs 1A, B, 4A, G, J, 5A, H). Three mighty, hook-like caudal cirri (CC) about 40-60 $\mu \mathrm{m}$ long (Figs 4A, L, 5C, I). Invariably six dorsal kineties (DK), each situated in narrow longitudinal pellicular groove (Fig. 4L, arrows); kineties 1 and 2 near left margin of ventral side, and both terminated posteriorly in a short row consisting of tightly spaced kinetosomes (Figs 1B, 5A; kineties 3-6 positioned on dorsal side, of which kinety 3 extends over the entire length of body, while the other three extend only to the caudal cirri (Figs 1C, 5C); dorsal bristles about $3 \mu \mathrm{m}$ long (Fig. 4K, arrows).

\section{Stomatogenesis}

Stomatogenesis begins with the appearance of the opisthe's oral primordium (OP), which appears as a small patch of kinetosomes within a subsurface pouch between cytostome and left marginal cirri (Figs 1D, 6A). Slightly later, the proter's oral primordium (POP) appears subcortically anterior to the parental $\mathrm{AZM}_{2}$ (Figs 1E, 6D; at the same time the OP begins to differentiate into membranelles. Both the POP and OP develop then by rapid proliferation of kinetosomes (Fig. 2A), and soon a small streak-like anlage for paroral membrane (PMA, anlage I) appears within the subcortical pouch, and is located opposite to the posterior end of the POP and OP, respectively (Fig. 2C, D), meanwhile the parental paroral membrane begins to disintegrate. Subsequently, two groups in the OP, each with 11 and 4 membranelles, and two groups in the POP, each with 5 and 4 membranelles, are differentiated and finally migrate onto the surface of cell (Figs 2E, 4H). Meanwhile, the PMA begins to lengthen along the right edge of each opening pouch; the parental $\mathrm{AZM}_{2}$ and $\mathrm{BC}$ become invisible. In the late stages, two groups of membranelles in two oral primordia are separated, and 11 membranelles in the OP and 5 membranlles in the POP migrate anteriorly (Fig. 3A). As in its congeners, the newly built 

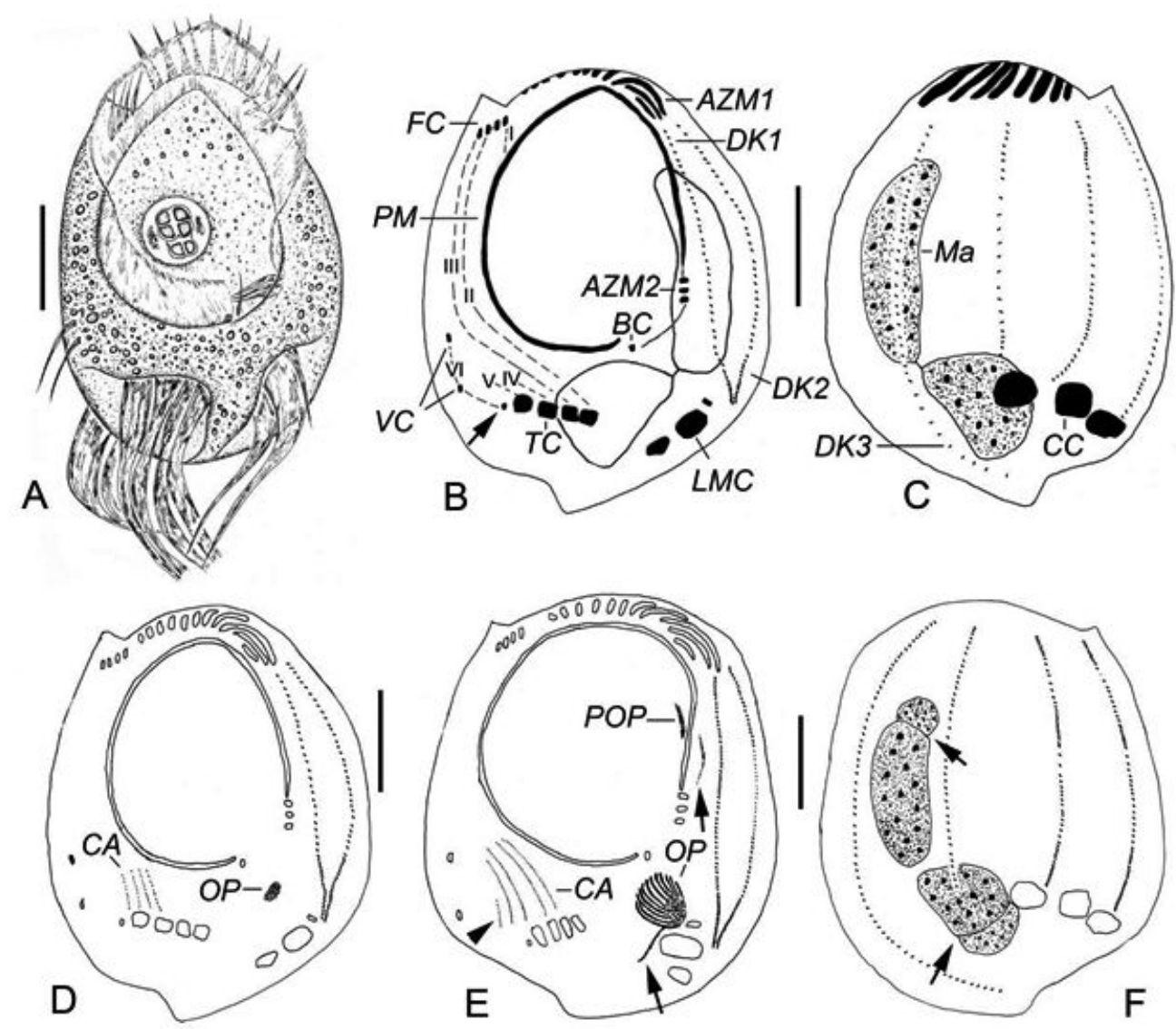

Fig. 1. Uronychia xinjiangensis n. sp. in vivo (A) and after protargol staining (B-F). (A) Ventral view of a representative individual. (B, C) Ventral and dorsal view of the holotype specimen, showing the ciliature and nuclear apparatus. Frontal-midventral-transverse cirri which originate from the same anlage are connected by a broken line. (D) Ventral view of an early divider, showing the formation of cirral anlagen and OP. (E, F) Ventral and dorsal view of the same early divider, showing the development of cirral anlagen and OP as well the formation of proter's oral primodirum, left marginal anlagen (arrows in E) and replication bands (arrow in F) and dorsal kinety anlagen in the two rightmost old structures; arrowhead indicates short cirral anlage. AZM1,2, anterior and proximal part of adoral zone of membranelles; BC, buccal cirrus; CA, cirral anlagen; CC, caudal cirri; DK1-3, dorsal kineties 1-3; FC, frontal cirri; LMC, left marginal cirri; Ma, macronuclear nodule; OP, opisther's oral primodium; PM, paroral membrane; POP, proter's oral primordium; TC, transverse cirri; VC, ventral cirri. Scale bars: $20 \mu \mathrm{m}$.

five membranelles will replace the posterior five membranelles of parental $\mathrm{AZM}_{1}$ in the proter, while the anterior (parental) six membranelles are retained to reform the new $\mathrm{AZM}_{1}$ of the proter; the first part in the opisthe will be the new AZM 1 of the opisthe (Fig. 3A). In the second group of AZM in both proter and opisthe, the posterior-most membranelle moves apart from the other three, and then migrates to the final position to differentiate into the new buccal cirrus (Fig. 3C, E).

\section{Development of somatic ciliature}

At about the same time as the OP is formed, four thread-like, frontal-ventral transverse cirral anlagen (CA), develop on the cell surface anterior to the trans- verse cirri (Figs 1D, E, 4A), and then lengthen. Soon the fifth anlage is generated right of them with kinetosomal proliferation (Fig. 1E), presenting as five streaks, they are appointed as CA II-VI from left to right. Apparently no parental cirri participate in the formation of these anlagen. Then the five anlagen proliferate and extend to its maximum length before they divide into two sets as the CA of both proter and opisthe (Fig. 2A). Subsequently, cirral anlagen begin to broaden at the posterior end, break apart and then migrate developing as distinct cirri (Fig. $2 \mathrm{C}, \mathrm{D}$ ). At this time, one short anlage (for the leftmost frontal cirrus) occurs near mid-portion of the anlage I in both proter and opisthe (Fig. 2E). Simultaneously, the cirral anlagen II-VI break apart into 3, 3, 2, 2, and 

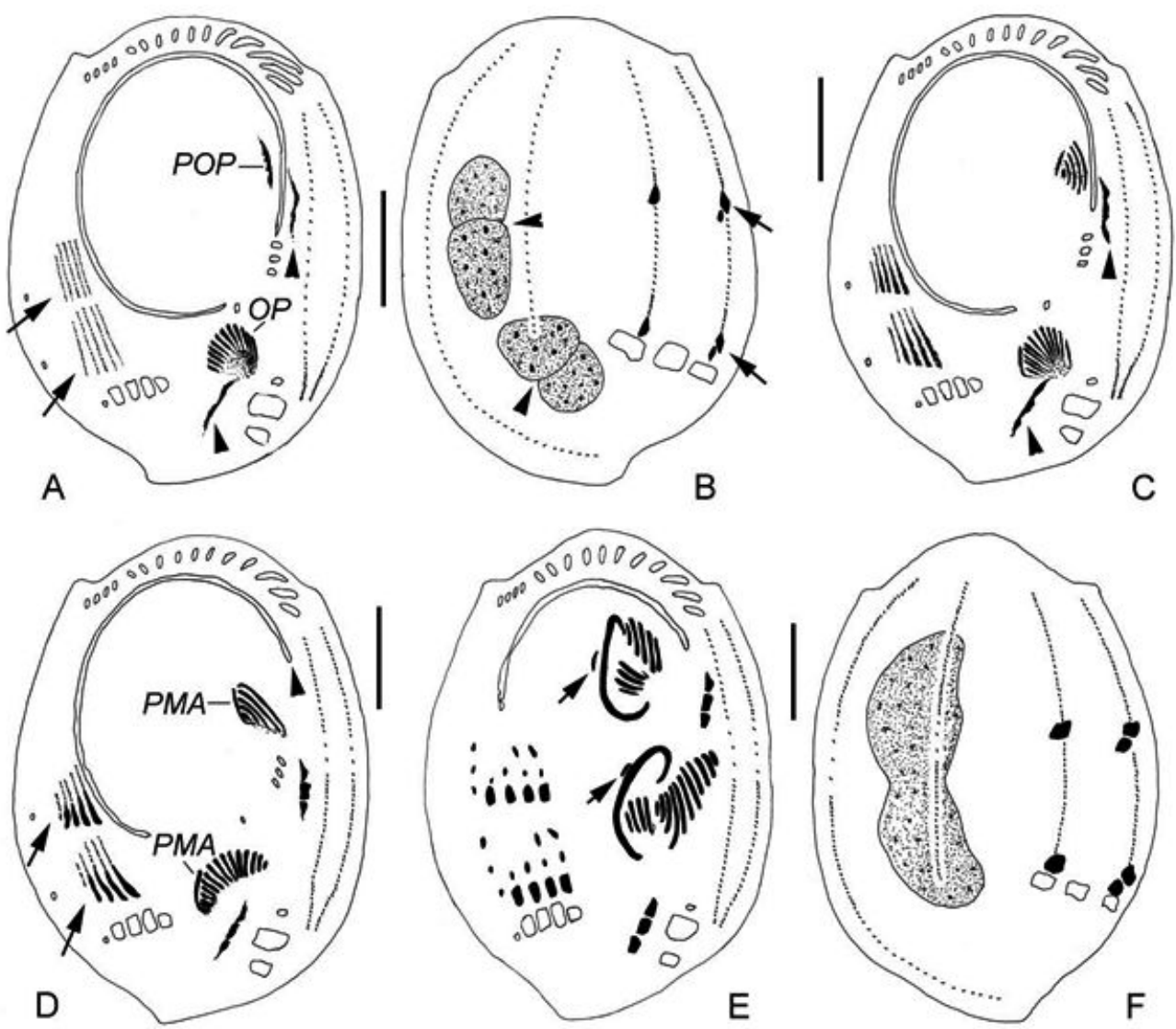

Fig. 2. Morphogenesis of Uronychia xinjiangensis n. sp. after protargol staining (A-F). (A, B) Ventral and dorsal view of the same specimen, arrows in A and B show cirral anlagen and two caudal cirri in the rightmost dorsal kinety anlagen of both proter and opisthe, respectively, arrowheads in A and B mark left marginal anlagen and replication bands, respectively. (C) Ventral view of a middle divider, arrowheads mark the development of left marginal anlagen. (D) Ventral view of a middle divider, showing the formation of paroral membrane anlagen and the segmentation of cirral anlagen (arrows), dedifferentiation of the old paroral membrane. (E, F) Ventral and dorsal view of the same late divider, showing the formation of new membranelles and cirri and other dorsal kineties anlagen, arrows show de novo formation of a frontal cirrus beside new paroral membrane OP, opisthe's oral primordium; PMA, paroral membrane anlage; POP, proter's oral primordium. Scale bars: $20 \mu \mathrm{m}$.

3 fragments (counted from left to right; Fig. 2E); these fragments finally develop into nine cirri, that is, 3 fronal, 2 ventral and 5 transverse cirri. The definite differentiation is: the anterior and middle segments in anlage II and the anterior one in anlage III will become frontal cirri; the middle segment from anlage III and the anterior one from anlagen IV and $\mathrm{V}$ will be resorbed before or after cell division is finished; the anterior and middle segments from anlage VI develop into ventral cirri, the remaining will become transverse cirri (Fig. 5A, C).

The anlagen of left marginal cirri appear on the cell surface anterior to the AZM2 and left of buccal cavity in the proter and behind the OP and right of the old LMC in the opisthe (Fig. 1E, arrows), when the POP is formed. These anlagen then enlarge by proliferation of kinetosomes and two depressions are formed (Fig. 2A). At last, the anlagen segment into three parts as the cirral anlagen break apart (Figs 2C, D, E; 3A, C) and ultimately form the marginal cirri for the daughter cells (Fig. 3E).

On dorsal side, the development of dorsal kineties anlagen occurs at two levels within each old kinety and seems to follow a gradient from right to left (Fig. 1F). Soon, caudal cirri are generated as follows: two caudal cirri are formed at the posterior end of the rightmost anlage in both proter and opisthe, and one caudal cirrus is formed at the posterior end of the penultimate anlage from right (Figs 1F, 2B, F). During the formation of new caudal cirri, morphogenesis of the other four old dorsal kineties is undergoing. The proliferation of new basal bodies occurs within each old kinety (Fig. 2E, F). These anlagen gradually lengthen towards both ends of the body to replace the old kineties (Fig. 3A-D). 

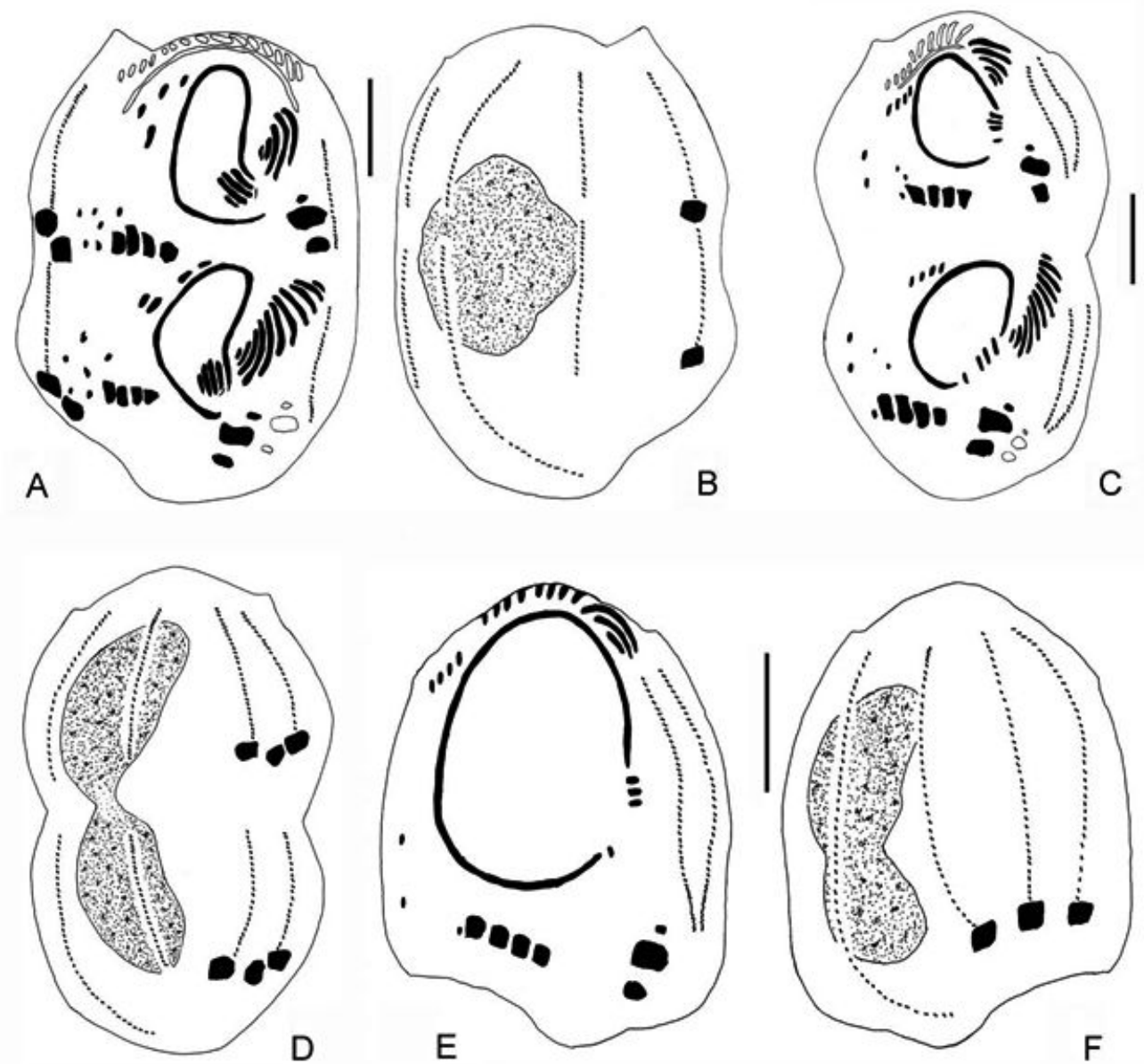

Fig. 3. Morphogenesis of Uronychia xinjiangensis n. sp. after protargol staining (A-F). (A, B) Ventral and dorsal view of the same late divider, showing migration of new structures and the formation of spherical fused macronucleus. (C, D) Ventral and dorsal view of the same late divider, five new membranelles combine with six retained membranelles to form anterior part of adoral zone of membranelles in the proter, the macronucleus dividing once. (E, F) Ventral and dorsal view of the same daughter cell just after fusion, showing infraciliature and nuclear apparatus. Scale bars: $20 \mu \mathrm{m}$.

\section{Nuclear apparatus}

In the early stage of morphogenesis, one replication band is recognized at far end of each macronuclear nodule (Fig. 1F) and then migrates towards the center of cell (Fig. 2B). At about the same time as the OP separate into two groups, DNA replication is completed, and two nodules begin to fuse (Fig. 2F). When the fusion is completed a globular mass is formed (Fig. 3B). In the late stage, it divides into two parts and gives one part to each daughter cell as the cell division is undergoing (Fig. 3D). At last, daughter cell acquire two macronuclear nodules as result of one dividing of macronucleus (Fig. 3F). Unfortunately, the development of the micronucleus was not observed.

\section{SSU rDNA sequence and phylogenetic analyses}

The SSU rRNA gene sequence of Uronychia xinjiangensis n. sp. was deposited in GenBank with accession number of KX147287. The length and GC content of the SSU rRNA gene are $1723 \mathrm{bp}$ and $44.63 \%$, respectively. Phylogenetic trees based on the SSU rRNA gene sequences using $\mathrm{ML}$ and $\mathrm{BI}$ algorithms are basically congruent, therefore, only ML tree is shown here with support values of both algorithms indicated on branches (Fig. 7). In both ML and BI trees, the family Uronychiidae Jankowski, 1975 is divided into two parts: one consists of the Uronychia, Paradiophrys and Apodiophrys (91 ML, 1.00 BI); and the other is formed with Diophrys, Diophryopsis, Heterodiophrys 

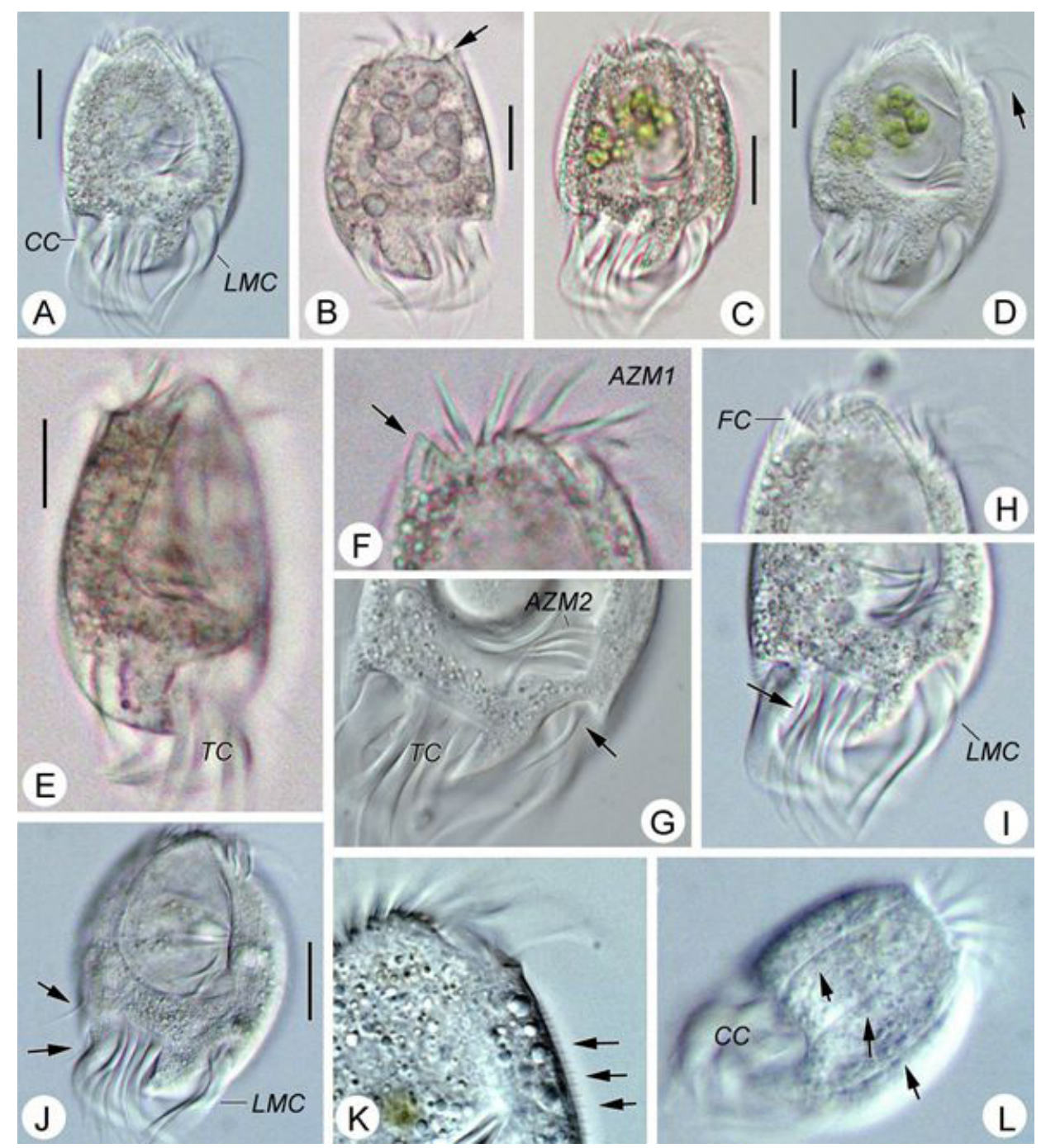

Fig. 4. Microphotographs of Uronychia xinjiangensis n. sp. from life (A-L). (A, C, D) Ventral views of different cells, showing variation of body shape, arrow shows cilia in AZM1. (B) Dorsal view showing inclusions, a small spur-like protrusion (arrow in B), and anterior membranelles (arrow in D). (E) Partially lateral view. (F) Anterior portion showing spur-like bulge (arrow) at anterior margin of body and AZM1. (G) Ventral view of posterior part showing AZM2, and small left marginal cirrus (arrow). (H) Ventral view of anterior part, showing frontal cirri. (I) Ventral view of posterior part, showing the fine rightmost transverse cirrus (arrow) and left marginal cirri. (J) Ventral view, showing two fine ventral cirri (arrows). (K) Depicting dorsal bristles. (L) Dorsal view, to show caudal cirri located at concave area and dorsal grooves (arrows). AZM1,2, anterior and proximal part of adoral zone of membranelles; CC, caudal cirri; FC, frontal cirri; LMC, left marginal cirri; TC, transverse cirri. Scale bars: $20 \mu \mathrm{m}$.

and Pseudodiophrys (81 ML, $1.00 \mathrm{BI})$. Up to now, there are 12 SSU rRNA gene sequences of Uronychia belonging to four morphospecies and an unidentified form in NCBI database and all of them cluster together to form a monophyletic clade with full support value (as shown in Fig. 7). Pairwise sequence similarities between $U$. xinjiangensis $\mathrm{n}$. sp. and its congeners range from $99.88 \%$ to $98.19 \%$ (i.e. the divergence range from 0.12 to 1.81 ) (Table 2).

\section{DISCUSSION}

\section{Morphological comparison with its congeners}

As mentioned above, so far only four morphospecies are included in the genus Uronychia. In terms of body shape and size, number of macronuclear nodules and structure of oral apparatus and cirral arrangement, our form resembles $U$. setigera and $U$. binucleata very 


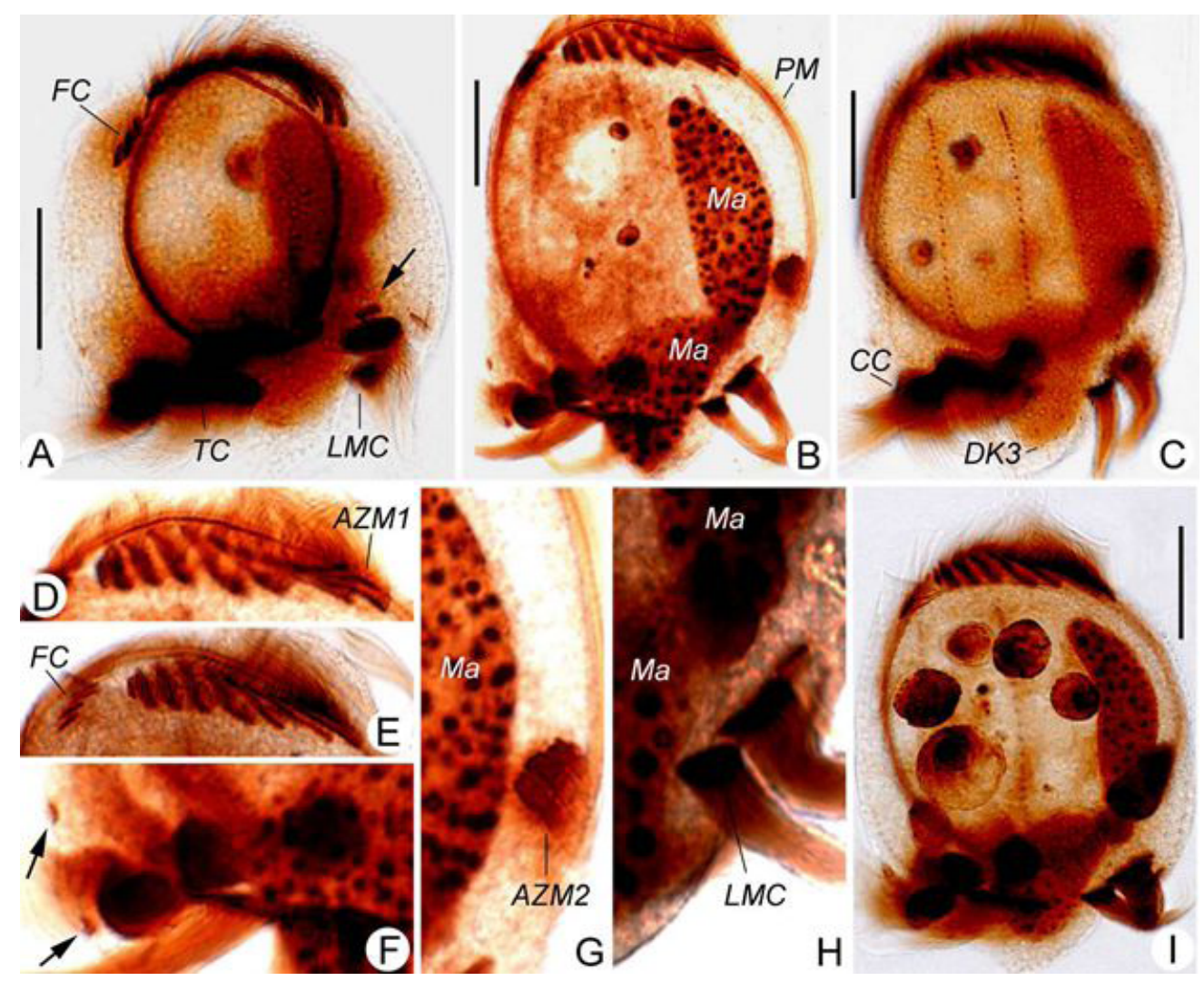

Fig. 5. Photomicrographs of Uronychia xinjiangensis n. sp. after protargol staining (A-I). (A-C, I) Ventral and dorsal views of specimens at interphase, showing ciliature and macronuclear nodules, arrow showing the small left marginal cirrus. (D, E) Anterior view, to show AZM1 and frontal cirri. (F) Arrows show two fine ventral cirri. (G, H) Depicting AZM2 and left marginal cirri. AZM1,2, anterior and proximal part of adoral zone of membranelles; CC, caudal cirri; DK3, dorsal kinety 3; FC, frontal cirri; LMC, left marginal cirri; Ma, macronuclear nodule; PM, paroral membrane; TC, transverse cirri. Scale bars: $20 \mu \mathrm{m}$.

well, however, differs in having three (vs. four) membranelles in the posterior part of adoral zone of membranelles, more basal body pairs in the leftmost dorsal kinety (ca. 36 pairs vs. ca. 15 or 30) (Song and Wilbert 1997; Song et al. 2004; Shi and Song 1999). Both Uronychia transfuga and $U$. multicirrus are larger forms (150-280 or 120-200 $\mu \mathrm{m})$ and possess beaded macronuclear nodules (Curds and Wu 1983; Song 1997, 1999; Shi and Song 1999). Furthermore, the latter has long row of ventral cirri (6-8 vs. 2 in the new species). Thus these two species cannot be confused with $U$. xinjiangensis $\mathrm{n}$. $\mathrm{sp}$.

\section{Morphogenetic features in Uronychia}

All known species of Uronychia have been morphogenetically investigated using silver staining methods (e.g. Hill 1990; Wilbert 1995; Shi and Song 1999; Song et al. 2004; Shen et al. 2009). The present work further confirms that Uronychia species exhibit very similar developmental mode of cortical ciliature and nuclear apparatus. These common features are as follows: (1) The oral primordium (OP) in both proter and opisthe are de novo formed in a subcortical pouch; (2) the parental AZM will be partly retained by the proter, i.e. the newly built membranelles formed in the OP will replace the $\mathrm{AZM}_{2}$ and the leftmost 5 parental ones in the parental $\mathrm{AZM}_{1}$; (3) five frontal ventral transverse cirral anlagen in both proter and opisthe are derived from the dividing of primary primordium; (4) the anlagen of the leftmost frontal cirrus and left marginal cirri develop de novo; (5) dorsal morphogenesis proceeds within the old kineties and three caudal cirri are formed at the posterior ends of the two rightmost dorsal kineties. However, Uronychia xinjiangensis $\mathrm{n}$. sp. differs in forming 3 (vs. 4 in all congeners) membranelles in the $\mathrm{AZM}_{2}, 2$ (vs. 5-8 in U. multicirrus and several to more 

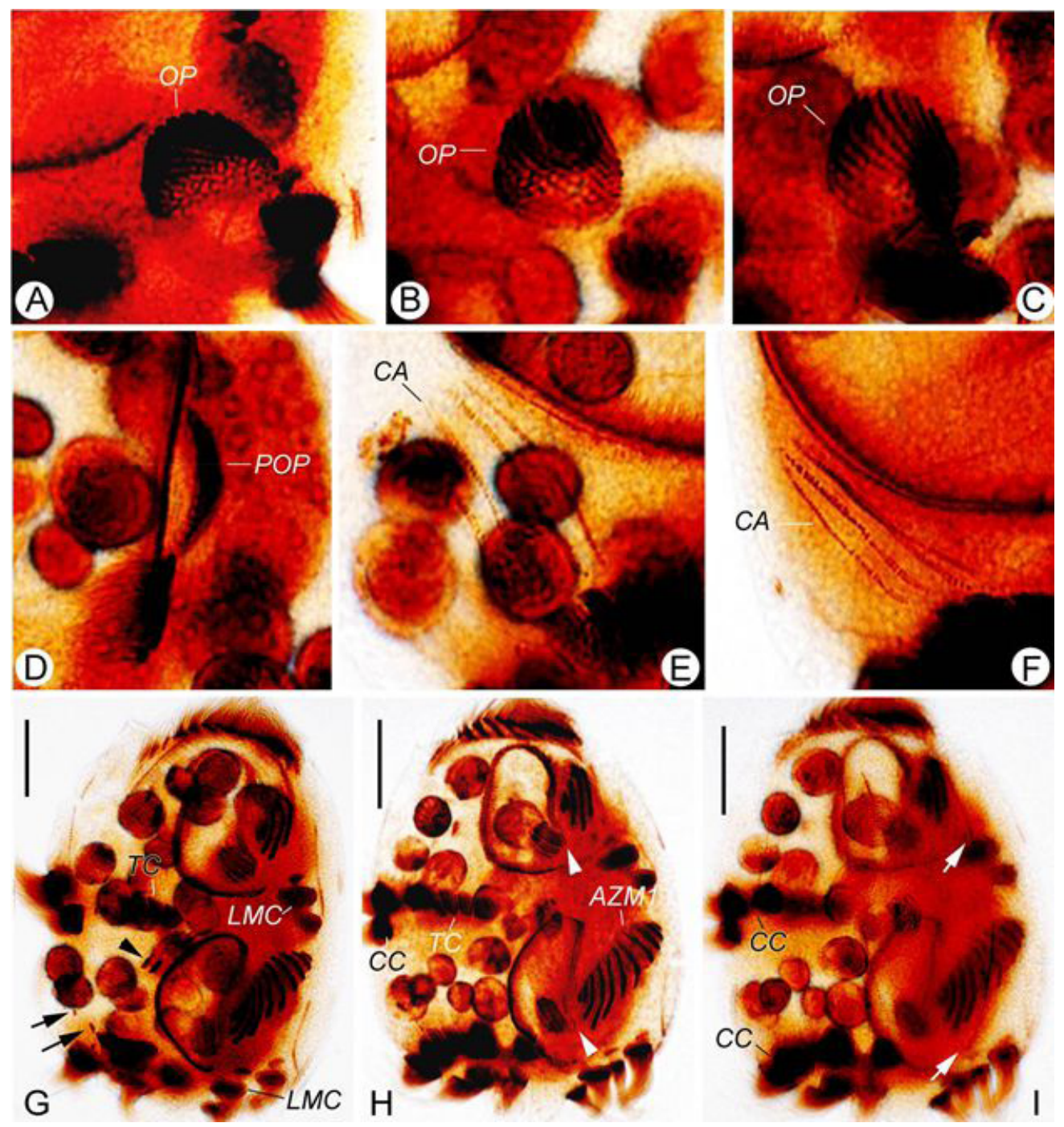

Fig. 6. Photomicrographs of Uronychia xinjiangensis n. sp. after protargol staining (A-I). (A-C) Opisthe's oral primordium at early dividers. (D) Proter's oral primordium. (E, F) Fontal-ventral-transverse cirral anlagen of early dividers. (G) A later divider showing the completion of development of oral primordium and cirral anlagen, arrows and arrow show newly formed ventral and frontal cirri respectively in the opisthe. (H, I) The same late divider showing the posterior part of adoral zone of membranelles (arrowheads) and the longest dorsal kinety 3 (arrows). AZM1, the anterior part of adoral zone of membranelles; CA, cirral anlagen; CC, caudal cirri; LMC, left marginal cirri; OP, opisthe's oral primordium; POP, proter's oral primordium; TC, transverse cirri. Scale bars: $20 \mu \mathrm{m}$.

than 10 in $U$. transfuga) macronuclear nodules during binary fission, which supports the separation of these five species.

Like several related euplotids (e.g. Diophrys, Pseudodiophrys, Euplotes), some caudal cirri are derived from the posterior end of the rightmost dorsal kinety in Uronychia (Hu 2008; Song et al. 2009; Shao et al. 2010; Fan et al. 2013), which is in accordance with the rightmost caudal cirrus often originated from the posterior end of the 4 th dorsal kinety in some hypotrichs
(Berger 1999; Kumar et al. 2014; Li et al. 2016; Lu et al. 2017; Luo et al. 2017), and implies this feature is an ancestral one. However, compared with other euplotids, Uronychia species demonstrate several unusual characters: (1) undulating membrane anlage forming only paroral membrane just like Euplotes and Certesia rather than paroral and endoral membranes as in Diophrys and most diverse hypotrichs, which seems to suggest it is a plesiomorphic character; nevertheless, it cannot be excluded that the highly differentiated paroral membrane 


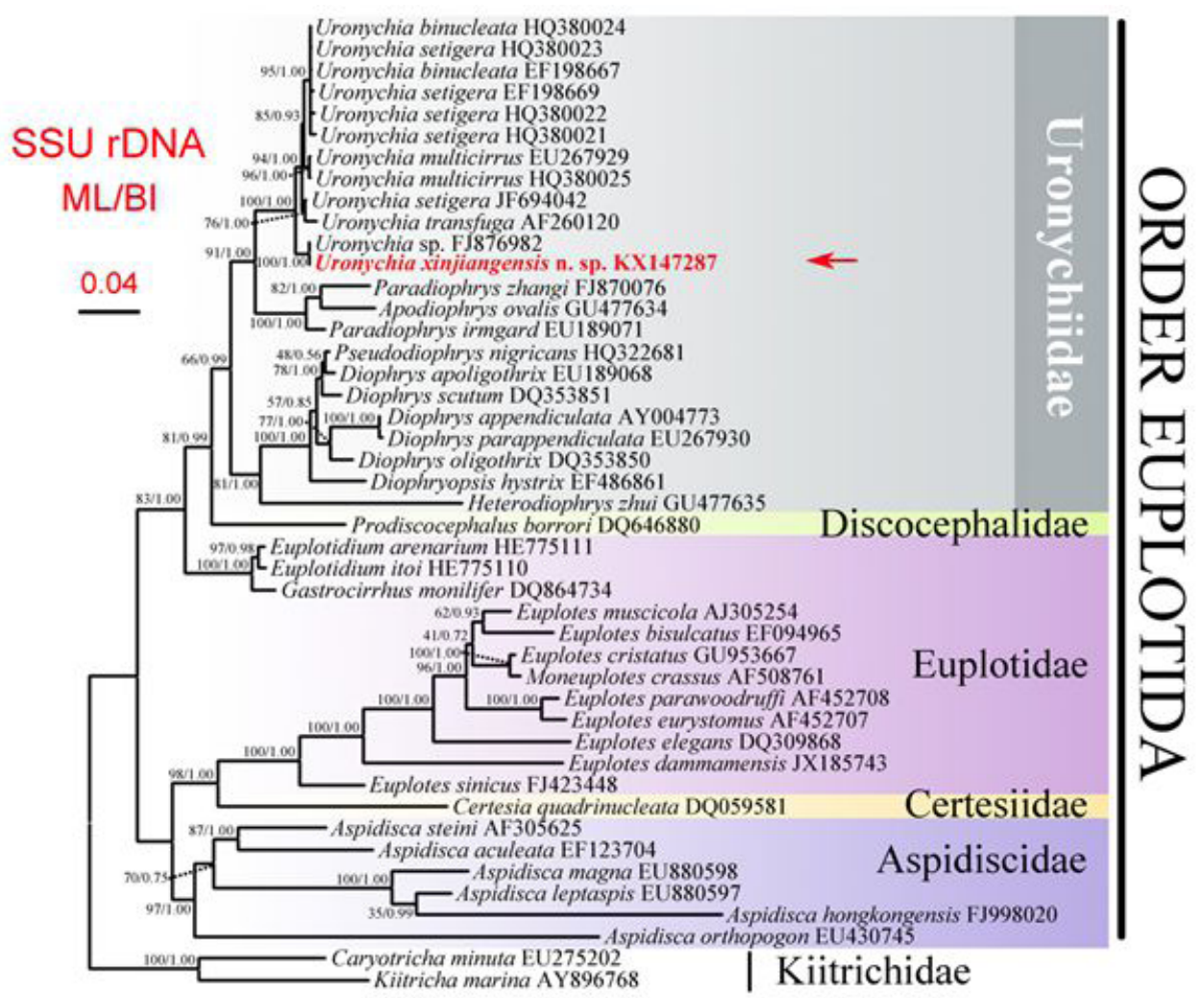

Fig. 7. Phylogenetic tree inferred by ML and BI of SSU rRNA gene sequences. Numbers near branches denote ML bootstraps value/BI posterior probability value. '*' indicates topology that differ between ML and BI phylogenies. All branches are drawn to scale. The scale bar corresponds to 5 substitutions per 100 nucleotide positions. GenBank accession numbers are given for each species. Classification is mainly according to Lynn (2008).

in Uronychia is a divergent feature as the basal bodies in it are arranged in short rows, which is distinct from anarchic distribution in Euplotes; (2) de novo formation of OP in the proter (vs. no OP in other euplotids); and (3) the piece-together-mode of the $\mathrm{AZM}_{1}$ in the proter (vs. complete retaining of parental AZM or partly renewal of membranelles at proximal portion).

\section{Molecular comparison with congeners}

The phylogenetic analysis is consistent with the morphological result. U. xinjiangensis $\mathrm{n}$. sp. clusters with the congeners to form the monophyletic clade with full value, which supports the monophyly of Uronychia. The divergence of SSU rRNA gene sequences between $U$. xinjiangensis and four valid Uronychia species is over 20 base pairs. Such differences, combined with its unique morphological and morphogenetic features, corroborate the establishment of this species as a distinctive member of Uronychia. The SSU rRNA gene sequence variation between $U$. xinjiangensis and Uro- nychia sp. is 2 base pairs and two forms cluster together to form a sister branch with full support value in phylogenetic trees (Fig. 7). From the molecular analyses, these two forms are very likely conspecific, however, the lack of morphologic description makes it unsolved.

Acknowledgements. This work was supported by the National Natural Science Foundation of China (41776133, 31272262), Zhejiang Provincial Natural Science Foundation and Zhejiang Key Scientific \& Technological Innovation Team Project (Y3100128, 2010R50039-20), and the Hangzhou Key Laboratory for Animal Adaptation and Evolution (20100333T05). Thanks are due to $\mathrm{Mr}$. Zicong Li, an ex-graduate student of the Laboratory of Protozoology at the Ocean University of China, for extracting DNA, and Dr. Feng Gao for gene sequence analyses.

\section{REFERENCES}

Agamaliev F. G. (1971) Complements to the fauna of psammophilic ciliates of the western coast of the Caspian Sea. Acta Protozool. 8: 379-404 (in Russian with English summary)

Berger H. (1999) Monograph of the Oxytrichidae (Ciliophora, Hypotrichia). Monogr. Biol. 78: 1-1080 
Borror A. C. (1972) Tidal marsh ciliates (Protozoa): morphology, ecology, systematics. Acta Protozool. 10: 29-71

Bullington W. E. (1940) Some ciliates from Tortugas. Pap. Tortugas Lab. 32: 179-221

Calkins G. N. (1911) Regeneration and cell division in Uronychia. J. Exp. Zool. 10: $95-116$

Carey P. G. (1992) Marine interstitial ciliates. Chapman and Hall, London

Chen Z., Song W. (2001) Phylogenetic positions of Uronychia transfuga and Diophrys appendiculata (Euplotida, Hypotrichia, Ciliophora) within hypotrichous ciliates inferred from the small subunit ribosomal RNA gene sequences. Eur. J. Protistol. 37: 291-301

Chen Z., Song W., Warren A. (2003) Species separation and identification of Uronychia spp. (Hypotrichia: Ciliophora) using RAPD Fingerprinting and ARDRA Riboprinting. Acta Protozool. 42: 83-90

Curds C. R., Wu I. C. H. (1983) A review of the Euplotidae (Hypotrichida, Ciliophora). Bull. Br. Mus. Nat. Hist. (Zool.) 44: 191-247

Fan Y., Warren A., Al-Farraj S. A., Chen X., Shao C. (2013) Morphology and SSU rRNA gene-based phylogeny of two $\mathrm{Di}$ ophrys-like ciliates from northern China, with notes on morphogenesis of Pseudodiophrys nigricans (Protozoa, Ciliophora). J. Morphol. 274: 395-403

Gao F., Huang J., Zhao Y., Li L. F., Liu W. W., Miao M., Zhang Q. Q., Li J.M., Yi Z. Z., El-Serehy H. A., Warren A., Song W. (2017) Systematic studies on ciliates (Alveolata, Ciliophora): progress and achievements based on molecular information. Eur. J. Protistol. 61: 409-423

Hall T. A. (1999) BioEdit : a user-friendly biological sequence alignment editor and analysis program fro Windows 95/98/NT. Nucleic Acids Symp. Ser. 41: 95-98

Hill B. F. (1990) Uronychia transfuga (O. F. Müller, 1786) Stein, 1859 (Ciliophora, Hypotrichida, Uronychidae): cortical structure and morphogenesis during division. J. Protozool. 37: 99107

$\mathrm{Hu}$ X. (2008) Cortical structure in non-dividing and dividing $D i$ ophrys japonica spec. nov. (Ciliophra, Euplotida) with notes on morphological variation. Eur. J. Protistol. 44: 115-129

Huang J., Chen Z., Song W., Berger H. (2014) Three-gene based phylogeny of the Urostyloidea (Protista, Ciliophora, Hypotricha), with notes on classification of some core taxa. Mol. Phylogenet. Evol. 70: 337-347.

Huang J., Dunthorn M., Song W. (2012) Expanding character sampling for the molecular phylogeny of euplotid ciliates (Protozoa, Ciliophora) using three markers, with a focus on the family Uronychiidae. Mol. Phylogenet. Evol. 63: 598-605

Kahl A. (1932) Urtiere oder Protozoa. I: Wimpertiere oder Ciliata (Infusoria), 3. Spirotricha. Tierwelt Dtl. 25: 399-650

Kattar M. R. (1970) Estudo dos protozoários cilados psamófilos do litoral Brasileiro. Zool. Boil. Mar. N.S. 27: 123-206

Kim S. J., Min G. S. (2011) First record of three Uronychia species (Ciliophora: Spirotrichea: Euplotida) from Korea. Korean J. Syst. Zool. 27: 25-33

Kirby H. (1934) Some ciliates from salt marshes in California. Arch. Protistenkd. 82: 114-133

Kumar S., Bharti D., Marinsalti S., Insom E., Terza A. (2014) Morphology, morphogenesis, and molecular phylogeny of Paraparentocirrus sibillinensis n. gen., n. sp., a "Stylonychine Oxytrichidae" (Ciliophora, Hypotrichida) without transverse cirri. J. Eukaryot. Microbiol. 61: 247-259
Li J., Chen X., Xu K. (2016) Morphology and small subunit rDNA phylogeny of two new marine urostylid ciliates, Caudiholosticha marina sp. nov. and Nothoholosticha flava sp. nov. (Ciliophora, Hypotrichia). J. Eukaryot. Microbiol. 63: 460-470

Lu X., Huang J., Shao C., Al-Farraj S. A., Gao S. (2017) Morphology and morphogenesis of a novel saline soil hypotrichous ciliate, Gonostomum sinicum nov. spec. (Ciliophora, Hypotrichia, Gonostomatidae), including a report on the small subunit rDNA sequence. J. Eukaryot. Microbiol. 64: 632-646

Luo X., Li L., Wang C., Bourland W., Lin X., Hu X. (2017) Morphologic and phylogenetic studies of two hypotrichous ciliates, with notes on morphogenesis in Gastrostyla steinii Engelmann, 1862 (Ciliophora, Hypotrichia). Eur. J. Protistol. 60: 119-133

Lynn D. H. (2008) The ciliated protozoa: characterization, classification and guide to the literature, third ed. Springer, Dordrecht

Mansfeld K. (1923) 16 neue oder wenig becannte marine Infusorien. Arch. Protistenkd. 46: 97-140

Medlin L., Elwood H. L., Stickel S., Sogin M. L. (1988) The characterization of enzymatically amplified eukaryotic 16S-like rRNA-coding regions. Gene 71: 491-499

Müller O. F. (1786) Animalcula infusoria fluviatilia et marina, quae Detexit, Systematice Descripsit et ad Vivem Delineari Curavit. Mölleri, Havniae

Nylander J. A. A. (2004) MrModeltest 2.2. Program distributed by the author. Evolutionary Biology Centre, Uppsala University, Uppsala, Sweden

Sela I., Ashkenazy H., Katoh K., Pupko T. (2015) GUIDANCE2: accurate detection of unreliable alignment regions accounting for the uncertainty of multiple parameters. Nucleic Acids Res. $\mathbf{4 3}$ (Web Server issue): W7-W14; doi: 10.1093/nar/gkq443

Shao C., Ma H., Gao S., Al-Rasheid A. K., Song W. (2010) Reevaluation of cortical developmental patterns in Euplotes (s.1.), including a morphogenetic redescription of E. charon (Protozoa, Ciliophora, Euplotida). Chin. J. Oceanol. Limnol. 28: 593-602

Shen Z., Shao C., Gao S., Lin X., Li J., Hu X., Song W. (2009) Description of the rare marine ciliate, Uronychia multicirrus Song, 1997 (Ciliophora; Euplotida) based on morphology, morphogenesis and SS rRNA gene sequence. J. Eukaryot. Microbiol. 56: $296-304$

Shi X. (2006) The application of improved protargol method in $\mathrm{Pa}$ raurostyla. Bull. Biol. 41: 52 (in Chinese)

Shi X., Song W. (1999) Morphogenetic studies on Uronychia setigera (Ciliophora, Hypotrichida). Acta Hydrobiol. Sin. 23: 146150 (in Chinese with English summary)

Song W. (1996) Morphogenetic studies on Uronychia uncinata (Protozoa, Ciliophora) during its asexual division. Acta Oceanol. Sin. 15: 93-99

Song W. (1997) On the morphology and infraciliature of a new marine hypotrichous ciliate, Uronychia multicirrus sp. n. (Ciliophora: Hypotrichida). Acta Protozool. 36: 279-285

Song W. (1999) Redefinition of the marine ciliate genus, Uronychia. In: Song, W. et al. (eds.), Progress in Protozoology. Qingdao Ocean University Press, Qingdao. p. 177-187

Song W., Wilbert N. (1997) Morphological investigations on some free living ciliates (Protozoa, Ciliophora) from China seas with description of a new hypotrichous genus, Hemigastrostyla nov. gen. Arch. Protistenkd. 148: 413-444

Song W., Shao C., Yi Z., Li L., Warren A., Al-Rasheid K. A. S., Yang J. (2009) The morphology, morphogenesis and SSrRNA gene sequence of a new marine ciliate, Diophrys apoligothrix spec. nov. (Ciliophora; Euplotida). Eur. J. Protistol. 45: 38-50 
Song W., Wilbert N., Chen Z., Shi X. (2004) Considerations on the position of Uronychia and related euplotids based on the data of ontogeny and 18S rRNA gene sequence analyses, with morphogenetic redescription of Uronychia setigera Calkins, 1902 (Ciliophora: Euplotida). Acta Protozool. 43: 313-328

Stamatakis A., Hoover P., Rougemont J. (2008) A rapid bootstrap algorithm for the RAxML web-servers. Syst. Biol. 75: 758-771

Stein F. (1859) Über die während der verflossenen Sommerferien in der Ostsee bei Wismar beobachteten Infusorienformen, unter denen sich mehrere neue Gattungen befanden. Abh. K. böhm. Ges. Wiss. 10 (year 1857): 62-63

Tamura K., Stecher G., Peterson D., Filipski A., Kumar S. (2013) MEGA6: Molecular evolutionary genetics analysis version 6.0. Mol. Biol. Evol. 30: 2725-2729

Taylor C. V. (1928) Protoplasmic reorganization in Uronychia uncinata $\mathrm{n}$. sp. during binary fission and regeneration. Physiol. Zool. 1: $1-26$

Valbonesi A., Luporini P. (1990) A new species of Uronychia (Ciliophora, Hypotrichida) from Antarctica: Uronychia antarctica. Boll. Zool. 57: 365-367
Wang C. C., Nie D. (1932) A survey oft the marine protozoa of Amoy. Contr. Biol. Lab. Sci. Soc. China Zool. Ser. 8: 285-385

Wallengren J. (1900) Zur Kenntnis der vergleichenden Morphologie der hypotrichen Infusorien. Bih. K. Svenska Vetensk. Akad Handl. 26: 1-31

Wilbert N. (1995) Benthic ciliates of salt lakes. Acta Protozool. 34: 271-288

Wilbert N., Kahan D. (1981) Ciliates of solar lake on the Red Sea shore. Arch. Protistenkd. 124: 70-95

Yi Z., Song W., Clamp J. C, Chen Z., Gao S., Zhang Q. (2009) Reconsideration of systematic relationships within the order Euplotida (Protista, Ciliophora) using new sequences of the gene coding for small-subunit rRNA and testing the use of combined data sets to construct phylogenies of the Diophrys-complex. Mol. Phylogen. Evol. 50: 599-607

Young D. B. (1922) A contribution to the morphology and physiology of the genus Uronychia. J. Exp. Zool. 36: 353-395

Received on $22^{\text {nd }}$ October, 2017; revised on $18^{\text {th }}$ December, 2017; accepted on $27^{\text {th }}$ December; 2017 